\title{
ФОРМУВАННЯ ІНФОРМАЦІЙНОЇ КОМПЕТЕНТНОСТІ МАЙБУТНЬОГО ВЧИТЕЛЯ ЗАСОБАМИ ПРАКТИКО-ЗОРІЕНТОВАНОГО НАВЧАННЯ
}

\author{
Хамська Н. Б., Киналь А. Ю.
}

\section{ВСТУП}

В умовах інтеграції України у світовий освітній простір гостро постає питання реформування вищої професійної освіти, ключовою ідеєю якого є підготовка майбутніх фахівців, здатних працювати в умовах глобалізованого, інформаційного суспільства. Мова йде про здобуття якісної освіти, що базується на інтеграції теоретичних знань, умінь, набутого досвіду, відповідних особистісних параметрів - досягнення певного рівня професійної компетентності, ключовим складником якої $\epsilon$ інформаційна. Сформованість інформаційної компетентності майбутнього вчителя забезпечить його здатність визначати, оцінювати, використовувати інформаційні ресурси, застосовувати їх у професійній діяльності й повсякденному житті; раціонально використовувати інформаційні технології в процесі розв'язування завдань, дотримуватися норм, правил поведінки в інформаційно-комунікаційному просторі.

Одним із визначальних інструментаріїв, що може забезпечити формування інформаційної компетентності майбутнього вчителя, $€$ практико-зорієнтований підхід в освітньому процесі закладів вищої освіти.

Актуальність проблеми практико-зорієнтованого навчання підсилюється у зв'язку з потребами, що зростають, роботодавців щодо якісної підготовки фахівців. Окрім того, глобалізація, інформатизація всіх сфер суспільного розвитку вимагає підготовки фахівців, які були б конкурентоздатними на європейському та світовому ринках праці.

Зміна орієнтирів закладів вищої освіти в площину практикозорієнтованого навчання зумовлена також потребами системи шкільної освіти, у рамках якої реалізуються ідеї нової української школи. Значущість цієї проблематики підсилюється основними законодавчими документами, а саме: Законом України про вищу 
освіту $^{1}$, Законом про повну загальну середню освіту ${ }^{2}$, концепцією про дуальну освіту ${ }^{3}$.

Проблематика практико-зорієнтованого навчання в сучасній педагогіці та методиці професійної освіти не $\epsilon$ новою, оскільки їй присвячено низку наукових праць вітчизняних і зарубіжних учених. Так, В. Майковською досліджено практико-зорієнтоване навчання як засіб професіоналізації підготовки майбутніх фахівців в Україні ${ }^{4}$. У працях Г. Горбенко визначено особливості організації практикозорієнтованого навчання під час підготовки бакалаврів ${ }^{5}$. У дослідженнях І. Гузія обгрунтовано практико-зорієнтоване освітне середовище як ефективна умова формування конкурентоздатності майбутніх педагогів ${ }^{6}$. Р. Квасницькою схарактеризовано практикозорієнтований підхід як один із засобів професіоналізації навчання у вищих навчальних закладах ${ }^{7}$. Теоретико-методологічні засади практико-зорієнтованого підходу у формуванні професійнопедагогічної культури майбутніх учителів початкових класів висвітлено в монографії І. Пальшкової ${ }^{8}$. Н. Черв'яковою проведено теоретико-експериментальне дослідження щодо використання практико-зорієнтованих технологій у процесі професійної підготовки

1 Про вищу освіту : Закон України від 28.12.2014 № 76-VIII. Дата оновлення: 18.03.2020. URL: https://zakon.rada.gov.ua/laws/show/1556-18 (дата звернення: 27.04.2020).

${ }^{2}$ Про повну загальну середню освіту : Закон України від 16.01.2020 № 463-IX. URL: http://w1.c1.rada.gov.ua/pls/zweb2/webproc4_1?pf3511=66333 (дата звернення: 27.04.2020).

${ }^{3}$ Про схвалення Концепції підготовки фахівців за дуальною формою здобуття освіти : Розпорядження Кабінету Міністрів України від 19 вересня 2018 р. № 660-р. URL: https://zakon.rada.gov.ua/laws/show/660-2018-\%D1\%80 (дата звернення: 27.04.2020).

${ }^{4}$ Майковська В.I. Практико-зорієнтоване навчання як засіб професіоналізації підготовки майбутніх фахівців в Україні. Проблеми інженерно-педагогічної освіти. 2016. № 50-51. C. 161-167.

${ }^{5}$ Горбенко Г.В. Практико-зорієнтоване навчання під час підготовки бакалаврів Інституту журналістики Київського університету імені Бориса Грінченка. Інтегровані комунікаиіï. 2017. № 4. С. 80-86.

${ }^{6}$ Гузій І.С. Створення практико-зорієнтованого освітнього середовища як умова формування конкурентоздатності майбутніх педагогів професійного навчання комп’ютерного профілю в системі соціального партнерства. Обрії. 2017. № 2. C. $27-29$.

7 Квасницька Р.С. Практико-зорієнтований підхід як один із засобів професіоналізації навчання у вищих навчальних закладів. Модернізація економіки 8 умовах зростання суспільної свідомості: туризм, людиномірність, партнерство, кооперація : матеріали II Всеукраїнської науково-практичної інтернет-конференції (м. Полтава, 14 грудня 2017 р.). Полтава : ПУЕТ, 2017. С. 296-300.

8 Пальшкова I. Практико-зорієнтований підхід у формуванні професійнопедагогічної культури майбутніх вчителів початкових класів: теоретикометодологічний аспект : монографія. Одеса : Букаєв Вадим Вікторович, 2009. 339 с. 
майбутніх педагогів ${ }^{9}$. С. Бобраковим узагальнено особливості практико-зорієнтованої професійної підготовки магістрів освіти в університетах Німеччини ${ }^{10}$.

Аналіз психолого-педагогічної літератури дає підстави стверджувати, що, незважаючи на вагомий внесок у розроблення проблеми практичної підготовки майбутніх учителів, вона залишається актуальною й відкритою для наукового пошуку. Причиною $є$ недостатня теоретичне й методичне розроблення питань практико-зорієнтованого навчання майбутнього вчителя 3 огляду на сучасні тенденції розвитку глобалізованого, інформаційного суспільства. Це викликало суперечність між визнанням провідної ролі практико-зорієнтованого навчання майбутнього вчителя в його професійній підготовці й недостатньою розробленістю науковометодичного забезпечення практичної підготовки майбутнього фахівця в умовах вищої освіти; між потребами, що зростають, споживачів освітніх послуг, вимогами ринку праці в підготовці фахівців, рівень яких відповідав би викликам сьогодення, і недостатнім рівнем готовності до професійної діяльності в умовах вищої освіти. Це зумовило вибір теми дослідження «Формування інформаційної компетентності майбутнього вчителя засобами практико-зорієнтованого навчання».

\section{1. Можливості практико-зоріснтованого навчання}

\section{у формуванні інформаційної компетентності майбутнього вчителя}

У психолого-педагогічній i фаховій літературі практикозорієнтоване навчання розглядається як засіб орієнтації освітнього процесу на кінцевий продукт професійного навчання - конкретизовані види дій, засвоєні студентами у вигляді досвіду під час роботи 3 навчальною інформацією. За своєю сутністю практико-зорієнтоване навчання вважається одним із найбільш ефективних засобів професіоналізації навчання в закладах вищої освіти, оскільки забезпечує підготовку студентів до майбутньої професійної діяльності. Цей підхід орієнтує студента на засвоєння конкретних практичних дій, досвід застосування яких можливий у результаті інтеграції теорії й практики ${ }^{11}$.

9 Черв'якова Н.І. Практико-зорієнтовані технології професійної підготовки майбутніх педагогів: досвід теоретико-експериментального дослідження. Education And Pedagogical Sciences. Ocвiта та педагогічна наука. 2017. № 1 (166). С. 35-43.

${ }^{10}$ Бобраков С.В. Практико-зорієнтована спрямованість професійної підготовки вчителів у вищих навчальних закладах Німеччини : дис. ... канд. пед. наук : 13.00.01. Луганськ, 2014. 200 с.

${ }^{11}$ Майковська В.І. Практико-зорієнтоване навчання як засіб професіоналізації підготовки майбутніх фахівців в Україні. Проблеми інженерно-педагогічної освіти. 2016. № 50-51. C. 164 . 
У процесі професійної підготовки це дає можливість моделювати предметний зміст фахової діяльності і трансформувати навчальну діяльність студента в професійну діяльність майбутнього фахівця ${ }^{12}$, на думку Г. Горбенко, у максимально наближених до реального життя умовах $^{13}$. І. Пальшкова пропонує формувати професійний досвід студентів, занурюючи їх у професійне середовище під час навчальної, виробничої й переддипломної практики ${ }^{14}$.

Аналіз зарубіжного досвіду реалізації практико-зорієнтованого навчання в процесі професійної підготовки майбутніх фахівців свідчить, що найбільший потенціал притаманний таким міжнародним освітнім практикам, як модель дуального навчання (Німеччина), «Всесвітня ініціатива CDIO» (Conceive-Design-ImplementOperate/придумуй-розробляй-упроваджуй-керуй) $\quad$ (США $)^{15}, \quad$ моделювання предметного та соціального змісту професійної праці в навчальному процесі SEED (конкретні практичні технології) (Швеція) ${ }^{16}$, модель вільних мистецтв і наук (liberal arts and sciences) $(С Ш А)^{17}$, модель «корпоративного університету» $(\text { США })^{18}$, педагогіка майбутніх фахівців, що призначена для засвоєння теорії та практики й реалізується за допомогою насичення навчального процесу елементами практико-зоріснтованої освіти (Practice-Based Education Pedagogy) (Австралія) $)^{19}$.

12 Майковська В.І. Практико-зорієнтоване навчання як засіб професіоналізації підготовки майбутніх фахівців в Україні. Проблеми інженерно-педагогічної освіти. 2016. № 50-51. С. 161-167.

13 Горбенко Г.В. Практико-зорієнтоване навчання у підготовці бакалаврів реклами і зв'язків з громадськістю. Неперервна професійна освіта: теорія $i$ практика. 2015. Вип. 4 (45). С. 64-69.

14 Пальшкова I. Практико-зорієнтований підхід у формуванні професійнопедагогічної культури майбутніх вчителів початкових класів: теоретикометодологічний аспект : монографія. Одеса : Букаєв Вадим Вікторович, 2009. 339 с.

${ }^{15}$ CDIO Standards 2.0. URL: http://www.cdio.org/implementing-cdio/standards/12cdio-standards (дата звернення: 27.04.2020).

${ }^{16}$ SEED: Sweden's English Educational Database for tertiary education: Creating a platform for sharing and collaboration / Ph. Shaw Philip, M. Deutschmann, R. Hincks, J. Hudson, D. Minugh. 2008. URL: https://www.researchgate.net/publication/237497727 (дата звернення: 27.04.2020).

17 Van der Wende M. The emergence of liberal arts and sciences education in Europe 1, 2: A Comparative Perspective. The Evolution of Liberal Arts in the Global Age. Routledge, 2017. C. 106-126.

${ }^{18}$ Kurbatov S. University Rankings and the Problem of Competitiveness of National Universities of Post-Soviet Countries in Global Educational Space: the Case of Ukraine. Evaluation in Higher Education. 2012. № 6 (2). P. 59-75.

${ }^{19}$ Peercy M., Troyan F. Making transparent the challenges of developing a practicebased pedagogy of teacher education. Teaching and Teacher education. 2017. T. 61. C. 26-36. 
Сутність практико-зорієнтованого навчання в професійній підготовці майбутніх фахівців активно досліджують німецькі вчені. Так, Д. Варнеке позиціонує його як активну форму організації професійної підготовки ${ }^{20}$. На думку Є.-М. Поста, у практикозорієнтованому навчанні зміст, технології, методи освітнього процесу спрямовані на формування в майбутніх фахівців практичних навичок роботи ${ }^{21}$. С. Пітч убачає в практико-зорієнтованому навчанні систему навчальних проблемних ситуацій, методичних і ситуаційних завдань, спроектованих на професійну підготовку майбутніх фахівців ${ }^{22}$. Ми відзначаємо, що в процесі професійної підготовки майбутнього вчителя практико-зорієнтоване навчання орієнтує його на вироблення, засвоєння умінь, навичок, досвіду педагогічної діяльності.

3 огляду на очевидний взаємозв'язок теоретичного та практичного компонентів професійної підготовки майбутніх фахівців, неможливо оминути увагою систему дуального навчання, яка широко використовується в німецькій системи освіти. Так, дуальну форму професійної освіти вважають однією з умов ефективного розв'язання завдань модернізації освіти ${ }^{23}$, перспективною формою одержання вищої освіти ${ }^{24}$, пріоритетним напрямом вищої професійної освіти в країнах європейського союзу ${ }^{25}$, важливим складником інноваційної підготовки майбутніх педагогів ${ }^{26}$.

Як зауважує М. Дернова, у європейському просторі вищої освіти вживаються різні словосполучення, які мають стосунок до дуального

${ }^{20}$ Warneke D. Aktionsforschung und Praxisbezug in der DaF-Lehrerausbildung. Kassel : Kassel Univ. Press, 2007. P. 39.

21 Post E.-M. Der Einsatz von handlungs-, erfahrungs und erlebnisorientierten Methoden in der Lehrerinnen und Lehrerfortbildung von pädagogischen Führungskräften zur Initiierung von Lernen. Studien zur Verknüpfung von Erfahrung, Reflexion und Transfer. Leipzig : Univ. Diss., 2010. P. 42.

${ }^{22}$ Pietsch S. Begleiten und begleitet werden. Praxisnahe Fallarbeit ein Beitragzur Professionalisierung in der universitären Lehrerbildung. Kassel : Kassel University Press, 2010. P. 44-45.

${ }^{23}$ Вем'ян В.Г., Тер-Ованес'ян В.Г. Дуальна форма професійної освіти як умова ефективного рішення завдань модернізації освіти. Психологія: реальність $i$ перспективи. 2015. № 5. С. 29-34.

${ }^{24}$ Кадемія М.Ю., Кобися А.П., Кобися В.М. Дуальне навчання - перспективна форма одержання вищої освіти. URL: http://ito.vspu.net/repozitariy/Kademiia/ stati_19/st_19.pdf (дата звернення: 27.04.2020).

$\overline{25}$ Калінічева Г. Дуальна форма навчання як пріоритетний напрям вищої професійної освіти в країнах європейського союзу. Ukraine European Union: From Partnership Towards Association. The Ukrainian Yearbook of the European Integration Studies. II. Lutsk : Teren, 2019. C. 151-16.

${ }^{26}$ Маринченко Є.О. Дуальне навчання як важливий складник інноваційної підготовки майбутніх педагогів професійного навчання. Cherkasy University Bulletin: Pedagogical Sciences. 2019. № 1. C. 69. 
навчання, а саме: альтернативне тренування (alternance training), навчання, що базується на діяльності (work-based learning), працеінтегроване навчання (work-integrated learning), діяльнісне навчання (work-related learning), гнучке навчання (flexible learning), кооперативна освіта (cooperative education) i проблемне навчання (problem solving). Усі вони базуються на загальному розумінні важливості створення умов для поєднання теоретичних знань, набутих у формальному навчальному середовищі, 3 практичними навичками, набутими на робочому місці ${ }^{27}$.

Свропейський центр розвитку професійної освіти (CEDEFOR) визначає дуальне навчання як засіб набуття знань, навичок шляхом виконання відповідних видів діяльності й рефлексії в професійному контексті або на робочому місці ${ }^{28}$. Г. Калінічева визначає дуальність як методологічну характеристику професійної освіти, що передбачає узгоджену взаємодію освітньої та виробничої сфери підготовки кваліфікованих кадрів певного профілю в рамках організаційновідмінних форм навчання ${ }^{29}$. Нині дуальне навчання в країнах Свропи позначається терміном work-based learning (WBL) і розглядається як база вищої професійної освіти, головним завданням якої є формування компетентностей, що $є$ необхідними для майбутньої професійної діяльності ${ }^{30}$.

Отже, дуальне навчання - це інтерактивний механізм надання професійної освіти, що базується на одночасному отриманні теоретичних знань у вищих навчальних закладах і практичних навичок і досвіду роботи в закладах, що відповідають профілю професійної підготовки майбутнього фахівця.

Ураховуючи особливості практико-зорієнтованого навчання, ми вважаємо, що воно забезпечує формування інформаційної компетентності майбутнього вчителя, а саме: здатності до пошуку, аналізу, класифікації, систематизації, адаптації інформації 3 метою

27 Дернова М.Г. Дуальна модель вищої професійної освіти дорослих: європейський досвід. Освіта дорослих: теорія, досвід, перспективи. 2014. № 2. C. 138 .

28 Work-Based Learning in Europe. Practices and Policy Pointers. European Comission. URL: http://ec.europa.eu/education/policy/vocational-policy/doc/alliance/ work-based-learning-in-europe_en.pdf (дата звернення: 27.04.2020).

29 Калінічева Г. Дуальна форма навчання як пріоритетний напрям вищої професійної освіти в країнах європейського союзу. Ukraine European Union: From Partnership Towards Association. The Ukrainian Yearbook of the European Integration Studies. II. Lutsk : Teren, 2019. C. 151-163.

${ }^{30}$ Work-Based Learning in Europe. Practices and Policy Pointers. European Comission. URL: http://ec.europa.eu/education/policy/vocational-policy/doc/alliance/ work-based-learning-in-europe_en.pdf (дата звернення: 27.04.2020). 
подальшого продуктивного використання ii в розв'язанні важливих практичних завдань; використання технічних засобів навчання; дотримуватися правил академічної доброчесності, уміння працювати в різних інформаційних середовищах; предметно характеризувати й аналізувати елементи освітнього процесу; виробляти надійні критерії оцінювання результатів власної діяльності як у звичних аудиторних умовах під час занять у 3ВО, так і в динамічно змінених під час практичної діяльності в загальноосвітніх навчальних закладах, а також виявляти відповідальність за результат власного навчання та професійної діяльності. Грунтуючись на вищезазначеному, ми розробили методику формування інформаційної компетентності майбутніх учителів філологічних спеціальностей засобами практикозорієнтованого навчання.

\section{2. Методика формування інформаційної компетентності майбутніх учителів філологічних спеціальностей засобами практико-зоріснтованого навчання}

Методика формування інформаційної компетентності майбутніх учителів філологічних спеціальностей засобами практикозорієнтованого навчання передбачала цілі, завдання, зміст, форми, методи та результативність.

Мета методики - формування інформаційної компетентності майбутніх учителів філологічних спеціальностей засобами практикозорієнтованого навчання.

Завдання методики: усвідомлення необхідності у формуванні інформаційної компетентності майбутнього вчителя засобами практико-зорієнтованого навчання; розуміння й осмислення знань 3 питань інформаційної компетентності; формування здатності до пошуку, аналізу, синтезу, оцінювання, класифікації інформації 3 подальшим її використанням для створення власного інформаційного продукту; набуття вмінь застосування інформаційно-комунікаційних технологій в освітньому процесі загальноосвітнього навчального закладу; оволодіння майбутніми вчителями навичок методики роботи 3 різними онлайн платформами, комп'ютерними та мобільними застосунками в інформаційному просторі; розвиток здатності до саморефлексії в питаннях інформаційної компетентості майбутнього вчителя.

Зміст методики:

- формування знань про систему сучасного інформаційного суспільства; про інформаційно-комунікативні технології, які можуть бути використані для розв'язання професійних завдань; про способи 
обробки, збереження, презентації, передачі інформації за допомогою інформаційно-комунікативних технологій;

- розвиток умінь роботи 3 операційними системами, утилітами, надбудовами над операційною системою та операційними оболонками 3 метою підготовки документації, навчально-методичних і наукових друкованих та електронних публікацій, ілюстративних і наочних матеріалів до професійних публічних виступів; використання соціальних мереж, утиліт, програм комунікаторів для створення професійного представництва в мережі Інтернет, телекомунікаційних технологій 3 певного предмета 3 урахуванням особливостей його викладання; орієнтування в інформаційному середовищі 3 метою виконання пошуково-аналітичних видів діяльності;

- формування мотивів прагнення та готовності до формування знань, умінь і навичок у галузі технічних, програмних засобів, інформатики, комп'ютерної техніки й інформаційно-комунікаційних технологій та інформації; бажання самостійно використовувати можливості комп'ютерних технологій у навчальній і позанавчальній діяльності; прагнення постійно самовдосконалюватися, ознайомлюючись із новими досягненнями в галузі інформатики; мотивація досягнення успіху в професійній діяльності за допомогою інформаційно-комунікаційних технологій;

- формування особистісних параметрів: сукупність ідеалів, переконань, поглядів, ставлень діяльності у сфері інформаційних процесів; упевненість у виборі інформаційних технологій, адекватне оцінювання власних можливостей у їх використанні та реалізації; наявність власної неупередженої точки зору щодо застосування інформаційно-комунікаційних технологій у професійній діяльності для розв'язання педагогічних завдань.

Процес формування інформаційної компетентності засобами практико-зорієнтованого навчання ми розглядаємо під час вивчення навчальних дисциплін, таких як «Методика виховної роботи», «Основи педагогічної майстерності», «Методика навчання іноземних мов», інструктивної, позашкільної, педагогічної практик в освітньому процесі Вінницького державного педагогічного університету імені Михайла Коцюбинського.

Так, під час практичних занять 3 методики виховної роботи студенти мали можливість планувати, моделювати та розробляти власні виховні проекти, які проводилися зі студентами для учнів загальноосвітніх навчальних закладів. Виконуючи ці завдання, ми спрямовували діяльність студентів на формування інформаційної компетентності, а саме: уміння працювати 3 різними джерелами інформації, аналізувати першоджерела, виокремлювати правдиву 
інформацію від неправдивої, правильно оформлювати посилання на автора, дотримуватися правил академічної доброчесності 3 метою уникнення плагіату; аналізувати й систематизувати отриману інформацію; створювати власний інформаційний продукт, використовуючи технічні та інформаційно-комунікаційні засоби на різних етапах виховного заходу; організовувати вхідне й вихідне анкетування; опрацьовувати результати анкетування та опитування; проводити рефлексію й робити підсумки виховного заходу.

Під час проведення фрагментів виховних заходів студенти використовували платформи Kahoot.com, Jeopardylabs.com для створення інтерактивних опитувань і вікторин, mentimeter.com для організації асоціограм і карти думок, організації рефлексії та збирання вражень учасників виховного процесу щодо проведеного заходу, GoogleForms для проведення анкетування з метою швидкої обробки та систематизації інформації. Окрім того, майбутні вчителі обирали актуальні теми для проведення дискусій і диспутів, а саме: «Мобільний телефон: друг чи ворог?», «Комп'ютерні ігри: перемога чи поразка»; проектної діяльності: «Соціальні медіа в житті різних поколінь», «Мій цифровий слід»; веб-квестів: «Комп'ютерний сленг», «Мовні особливості електронного листування»; соціальних досліджень серед підлітків: «Популярні додатки-комунікатори»; нестандартних виховних годин: «Суд над мобільним телефоном», заняттяпротистояння: «Живе спілкування проти електронного спілкування», «Електронна книга vs друкована книга» тощо.

Під час заняття з теми «Моделювання та проведення виховних форм роботи з учнями» студенти підготували та провели інтерактивну бесіду «Як запобігти булінгу». Проведення інтерактивної бесіди «Як запобігти булінгу» передбачало декілька етапів роботи студентів: підготовчий (підбір і систематизація матеріалів), проведення (робота 3 іншими студентами в аудиторії) та підсумковий (підведення підсумків, рефлексія учасників і саморефлексія). Підготовчий етап передбачав підбір змісту бесіди 3 теми «Як запобігти булінгу», опрацювання фахових i наукових статей із цієї проблематики, виокремлення ключової інформації у форматі тез та оформлення тезової інформації у форматі презентації PowerPoint, a також підбір коротких відеофрагментів 3 метою візуалізації теоретичних аспектів теми та організації практичної діяльності студентів під час аудиторного заняття. На цьому етапі студенти розвивали інформаційну компетентність майбутніх учителів, а саме: уміння ефективно шукати інформацію, працювати 3 джерелами та першоджерелами, розуміння авторського права, вирізняти факти від суджень, систематизувати 
інформацію, висувати гіпотези й оцінювати альтернативи ${ }^{31}$. Для ефективного пошуку інформації студенти вдосконалювали знання алгоритму роботи в інтернеті та соціальних мережах, зокрема пошук за ключовими словами, використання символів і хештегів: булінг, кібербулінг, цькування, кібернасилля. Окрім того, на цьому етапі передбачалося формування навичок фактчекінгу - перевірки текстів, фото, відеоматеріалів на правдивість чи неправдивість, порівняння знайденої інформації та визначення маркерів достовірності певного джерела.

На етапі проведення бесіди використано інтерактивні вправи «Хмара думок» на базі платформи Mentimeter.com, що дає можливість учасникам прописувати свої думки та ідеї у вигляді словосполучень у мобільному телефоні, а платформа автоматично систематизує та узагальнює результати у форматі динамічної різнокольорової хмари думок. Виклад інформації з теми бесіди посилювався візуальною підтримкою у формі відео, презентацій, графічних зображень тощо. Під час виконання онлайн вправи «Інформаційний барометр» учасники виражали ставлення до булінгу та аргументували свою позицію. Інформаційний виклад проблеми булінгу супроводжувався переглядом відеороликів, у яких запропоновано альтернативу розв'язання проблеми. Своє ставлення до розв'язання проблемної ситуації учасники бесіди виражали в новостворених групах у комунікаторі Viber. Кожна група отримала посилання 3 кодом доступу до спільної презентації на GoogleDisc (GoogleSheets) 3 окремим завданням: сформулювати алгоритм протидії булінгу в школі, удома, серед друзів, у мережі Інтернет - та оформити ці дії на окремому слайді в спільній презентації.

Виконання завдань інтерактивної бесіди формує інформаційну компетентність, а саме: основи критичного мислення (уміння обгрунтовувати свою позицію, використовуючи аргументацію, уміння ставити питання, навичку слухати інших і формувати контраргументи, уміння визначити причини та наслідки подій і явищ); ідентифікацію власних стереотипів (розуміння поняття стереотипу й механізмів його виникнення, уміння ідентифікувати стереотипи та дискримінацію, а також розвиває навички етичного спілкування); проведення паралелей між процесами чи явищами (уміння систематизувати інформацію, висувати гіпотези й оцінювати альтернативи); уміння проводити

31 Інтеграція інфомедійної грамотності у навчальний процес. Навчальнометодичні матеріали проєкту «Вивчай та розрізняй: інфо-медійна грамотність». Київ : IREX в Україні, 2019-2020. 
паралелі 3 теперішнім часом, сучасними умовами, ураховуючи соціокультурні, етнічні та економічні реалії сьогодення ${ }^{32}$.

Майбутні вчителі філологічних спеціальностей розвивали інформаційну компетентність під час вивчення навчальної дисципліни «Основи педагогічної майстерності». На заняттях із цієї дисципліни активно використовувалися такі методи навчання: дискусія, проблемне навчання, проектне навчання тощо, а також групові та фронтальні форми роботи. Під час занять майбутні фахівців набували досвіду роботи 3 використання відеофрагментів, моделювання проблемних педагогічних завдань, аналізувати їхні запропоновані розв'язки, пропонували власні ідеї. 3 метою збирання альтернативних розв'язків учасники освітнього процесу використовували технології WIKI, можливості синхронної роботи 3 текстовими файлами в документах Google, можливості голосування за допомогою платформ Mentimeter.com, Kahoot.com, GoogleForms тощо.

Так, під час практичного заняття 3 теми «Техніка використання методів педагогічного впливу» студенти самостійно підготували та провели марафон технік використання методів педагогічного впливу. Це здійснювалося на таких етапах: вибір учителем стратегії взаємодії; майстерність учителя виступати перед учнівською аудиторією; психолого-педагогічні аспекти взаємодії оратора й аудиторії; структура виступу; стиль і техніки побудови виступу; монолог як прихований діалог; майстерність педагогічного оцінювання: заохочення та покарання; основні правила оцінювальної діяльності вчителя; форми заохочення та покарання, вимоги до їх використання ${ }^{33}$.

Заняття проходило за трьома етапами: підготовчий, основний i підсумковий. Підготовчий етап передбачав самостійне опрацювання студентами теоретичного матеріалу 3 теми, який викладач попередньо розмістив на платформі GoogleClass. Окрім того, студенти самостійно об'єдналися в групи за інтересами й отримали завдання такого змісту: підготувати відеофрагменти, що чітко відображають техніку використання конкретного методу педагогічного впливу, використовуючи Інтернет ресурси. Виконання зазначених завдань формує інформаційну компетентність, а саме: інформаційну грамотність (уміння ефективно шукати інформацію, працювати зі

32 Інтеграція інфомедійної грамотності у навчальний процес. Навчальнометодичні матеріали проєкту «Вивчай та розрізняй: інфо-медійна грамотність». Київ : IREX в Україні, 2019-2020.

3 Хамська Н.Б. Робоча програма «Основи педагогічної майстерності» підготовки бакалаврів, галузі знань 01 Освіта/Педагогіка, за спеціальністю 014.02 Середня освіта (Мова і література (англійська, німецька, російська). Вінниця, 2019. $15 \mathrm{c}$. 
джерелами та першоджерелами, розуміння авторського права й авторського контенту, уміння систематизувати інформацію); комп'ютерну грамотність (уміння працювати 3 програмами для скачування й обробки відео); інноваційність і креативність (уміння втілювати ідеї завдяки онлайн-інструментам) $)^{34}$.

3 метою перевірки засвоєння теоретичних знань 3 теми використано платформу інтерактивного тестування kahoot.com. Ця платформа дає можливість розвивати такі аспекти інформаційної компетентності, як інформаційна грамотність (уміння відрізняти факти від суджень, систематизувати інформацію, висувати гіпотези й оцінювати альтернативи), візуальна грамотність (уміння аналізувати фото, символи, інфографіку, візуальні ряди та відеофрагменти), стійкість до впливів (базові навички емоційного інтелекту, уміння ідентифікувати вплив інформації на емоції), критичне мислення (уміння ставити запитання, обгрунтовувати власну позицію, оцінювати й інтерпретувати події, проводити паралелі 3 теперішнім часом, аналізувати передумови та причини подій, пропонувати можливі розв'язки критичних ситуацій тощо) $)^{35}$, комп'ютерна грамотність (уміння використовувати IКТ для досягнення освітньої мети).

На підсумковому етапі заняття здійснювалося узагальнення особливостей використання техніки методів педагогічного впливу за допомогою технологіï GoogleDocs, що дає змогу водночас редагувати текстовий документ декількома учасниками. На етапі рефлексії учасники аналізували подібний формат заняття з погляду ефективності його майбутньої професійної діяльності.

Отже, оволодіння основами педагогічної майстерності сприяло формуванню інформаційної культури майбутнього вчителя філологічного профілю, його інформаційної й технологічної грамотності, доцільності використання інформаційно-комунікаційних технологій у процесі навчання іноземної мови, виробленню вмінь застосовувати інформаційно-комунікаційні технології на різних етапах уроку 3 метою забезпечення педагогічної взаємодії викладача i студентів $^{36}$.

34 Інтеграція інфомедійної грамотності у навчальний процес. Навчальнометодичні матеріали проєкту «Вивчай та розрізняй: інфо-медійна грамотність». Київ : IREX в Україні, 2019-2020.

${ }^{35}$ Там само.

${ }^{36}$ Khamska N., Kynal A. Formation of Informational Competence of Future Teachers of Philological Specialties in the Process of Professional Training. Розвиток та модернізачія педагогічних та психологічних наук: досвід Польщі та перспективи України. Development and Modernisation of Pedagogical and Psychological Sciences: Experience of Poland and Prospects of Ukraine : Collective Monograph. Vol. 3. Lublin : Izdevnieciba «Baltija Publishing», 2017. P. 206-225. 
У процесі вивчення навчальної дисципліни «Методика навчання іноземних мов» ураховано не лише особливості організації дуальної освіти та практико-зорієнтованого навчання, а й вимоги нової програми 3 методики навчання іноземних мов, що впроваджується на факультеті іноземних мов Вінницького державного педагогічного університету 3 2016 року в рамках проекту Британських рад «Учитель нового покоління» ${ }^{37}$. Згідно 3 вимогами програми навчальної дисципліни «Методика навчання іноземних мов», освітній процес організовано у вигляді практичних занять за методикою змішаного навчання ${ }^{38}$. У такий спосіб студенти самостійно опрацьовують теоретичний матеріал за джерелами та посиланнями, що надаються викладачем перед практичним заняттям. Організація освітнього процесу за методикою змішаного навчання зорієнтована на формування інформаційної компетентності майбутнього вчителя, оскільки передбачає роботу в різних інформаційних середовищах, інформаційних оболонках, системах організації дистанційного навчання, таких як GoogleClassroom, блоги, програми-комунікатори, групи в соціальних мережах тощо. Це розвиває вміння швидко знаходити інформацію, аналізувати та класифікувати іiі, адаптувати до поставленого завдання, створювати власний інформаційний продукт у вигляді доповідей, рефератів, презентацій, фрагментів уроків тощо; здатність до участі в автоматизованих системах оцінювання знань, розроблених на платформах Moodle, GoogleForms, Kahoot.com, Quizlet.com тощо.

На особливу увагу в контексті практико-зорієнтованого навчання заслуговують заняття з методики навчання іноземних мов, під час яких студенти навчаються моделювати, розробляти уроки, відбирати їх навчальний контент, вправи відповідно до дидактичних цілей і завдань уроку, практикуються в проведенні фрагментів уроків.

Варто зазначити, що сформованість інформаційної компетентності майбутніх учителів філологічних спеціальностей впливає на розвиток іншомовної комунікативної, соціокультурної та мовленнєвої компетенцій.

Формування соціокультурної компетентності в умовах практикозорієнтованого навчання здійснюється шляхом використання

37 Проект «Шкільний учитель нового покоління». URL: http://www.britishcouncil.org.ua/teach/projects/presett (дата звернення: 27.04.2020).

38 Типова програма «Методика навчання англійської мови». Освітній ступінь бакалавра / О. Бевз, А. Гембарук, О. Гончарова, О. Заболотна, О. Змієвська, Л. Калініна, І. Каминін, Т. Коноваленко, І. Романишин, І. Самойлюкевич, О. Таран, Н. Тучина, К. Худик ; керівник проєкту: В. Іваніщева. Івано-Франківськ : НАIP, 2020. $126 \mathrm{c}$. 
інформаційно-пошукових сайтів, програм 3 перевірки інформації на правдивість, у тому числі різноманітних програм обробки та аналізу графічних об'єктів з метою виявлення підробки тощо. Формуванню комунікативної компетентності сприяє використання соціальних мереж, програм-комунікаторів, платформ для організації он-лайн відеоконференцій з носіями мови; створення комунікативних ситуацій на платформах для спільного доступу до інформації, таких як Wiki, документів Google тощо. Формування мовленнєвої компетентності здійснюється шляхом використання онлайн платформ для самостійного створення інтерактивних завдань 3 використанням актуальних лексичних одиниць i врахуванням особливостей цільової групи, наприклад, LearningApps.com, Quizlet.com, ігрових вправ Umapalata, платформ для формування навички аудіювання та письма Lyricstraining.com тощо.

Таким чином, методика формування інформаційної компетентності майбутнього вчителя засобами практико-зорієнтованого навчання $\epsilon$ запорукою ефективної підготовки фахівця до майбутньої професійної діяльності.

Для формування інформаційної компетентності майбутніх учителів філологічних спеціальностей важлива роль належить різним видам практик: пропедевтичній, інструктивно-методичній, позашкільній, педагогічній.

Пропедевтична практика $є$ початковим етапом практичної підготовки майбутнього вчителя англійської мови, який закладає основи успішного проходження таких видів практики, сприяє формуванню в студентів початкових професійних практичних навичок, загального уявлення про роботу вчителя, про етичний і психологічний аспекти цієї професії ${ }^{39}$.

Під час пропедевтичної практики майбутні педагоги відвідують заняття зі спеціальності у школах та аналізують різні аспекти майбутньої професійної діяльності: особливості організації освітнього процесу на різних ступенях загальноосвітнього навчального закладу, можливості використання інформаційно-комунікативних технологій залежно від цілей уроку тощо.

Із цією метою студентам факультету іноземних мов Вінницького державного педагогічного університету під час відвідування уроків у КЗ «Вінницький технічний ліцей» запропоновано заповнити

39 Пропедевтична практика: програма для студентів ОКР «бакалавр». Галузь знань: 0203 «Гуманітарні науки», напрям підготовки: 6.020303 «Філологія. Мова і література (англійська)» / авт. Т.А. Авксентьєва, В.М. Галузяк, М.М. Гушеватий, Н.Б. Хамська, В.В. Каплінський ; Вінницький державний педагогічний університет імені М. Коцюбинського. Вінниця, 2012. С. 2. 
опитувальник щодо ефективності використання інформаційнокомунікаційних технологій в освітньому процесі. Головним критерієм аналізу уроку $\epsilon$ вплив ІКТ, цифрових освітніх ресурсів та інформаційної компетентності вчителя на результативність освітнього процесу. На допомогу студентам в аналізі уроку із цього аспекту запропоновано можливі види використання інформаційних технологій: презентації, мультимедіа, прикладні офісні програми (Word, Excel, PowerPoint, Publisher), спеціалізовані програми (наприклад, Mathlab, GRAN, Maple тощо), програми для проведення тестів, педагогічні програмні засоби (ППЗ), електронні підручники, планшети, колекція цифрових освітніх ресурсів (ЦОР), мережа Інтернет (наприклад, бібліотека електронних наочних посібників), інтерактивна дошка, електронний класний журнал, використання локальної мережі, телекомунікації.

Отже, під час цього виду практики студенти навчалися спостерігати та аналізувати урок і дії вчителя в аспекті використання інформаційнокомунікаційних технологій, цифрових освітніх ресурсів у професійній діяльності педагога.

Під час педагогічної практики студенти мають можливість побувати в ролі вчителя в умовах освітнього закладу. Саме практикозорієнтований підхід до професійної підготовки майбутнього фахівця може забезпечити його адаптацію до професійної діяльності, виробити вміння й навички працювати в сучасному інформаційно-освітньому середовищі.

Так, студенти 4 курсу факультету іноземних мов Вінницького державного педагогічного університету імені Михайла Коцюбинського під час педагогічної практики проводили уроки англійської та німецької мов у комунальному закладі «Вінницький технічний ліцей» із застосуванням сучасних комп'ютерно-орієнтованих завдань, завдань для мультимедійної інтерактивної дошки та сучасних засобів комунікації; виховні заходи 3 англійської мови («Інтернет: друг чи ворог»; «Моя безпека в мережі Інтернет», «Інтернет-приниження: чи $\epsilon$ вихід?», «Віртуальність проти реальності», «Інтернет: за і проти» тощо); організовували виховні заходи («Інтернет у нашому житті», «Пост у мережі Інтернет: вірити чи ні»), тренінги («Моя особиста інформація в соціальних мережах»), колективні творчі справи («Сторінка Інстаграм нашої групи», «Життя поза віртуальною реальністю», «Перший мільйон: 3 історії мережі Інтернет»).

Під час розроблення та моделювання уроків майбутній фахівець готував дидактичні матеріали до уроку за допомогою інформаційнокомунікаційних технологій, а саме: використання знання алгоритмів пошуку інформації в різних пошукових системах, наприклад, 
за ключовими словами, хештегами, тощо; звернення до спеціалізованих сайтів (British Council, America English, Goethe Institut); розроблення самостійних завдань, що містили необхідні елементи мовного інструментарію (LearningApps.com, Quizlet.com, Umapalata.com).

Наводимо приклад, як студенти-практиканти організовували роботу на уроці, використовуючи інформаційні технології навчання.

Для створення дидактичного набору для уроку з використанням інформаційно-комунікаційних технологій ми навчали студентів структурування, аналізу, класифікації, систематизації завдань, дотримання дидактичних принципів логічності, послідовності, поетапності, посильності навчального матеріалу. Із цією метою ефективно використовували онлайн та офлайн презентації, створені за допомогою Power Point, Google Sheets, Prezi, Silde Dog, Slide Rocket, i розміщували завдання й посилання на завдання в електронному портфоліо або на блозі вчителя. Під час пояснення нового матеріалу майбутні вчителі використовували сайти для створення карти думок та асоціограм (Mindmeister, Coggle, Xmind, Bubbl.us, Mimondo). Для тренування, вправляння, автоматизації навичок студенти-практиканти використовували готові завдання 3 навчання аудіювання (Lyricstraining.com, Islcollective.com), навчання читання та письма (Plotgenerator), а також самостійно створювали завдання (Learningapps, Quizlet, Umapalata) тощо.

На початковому етапі використовували платформу Classdojo, на якій кожен учень міг обрати собі персонаж, увійти до віртуальної класної кімнати та повідомити про свою присутність на уроці. Окрім того, такі платформи, як Mentimeter.com, Kahoot.com, Plickers.com, EasyTestMaker, дали можливість проводити опитування про те, що вони очікують від уроку, визначити їхній настрій, організовувати зрізи попередніх знань тощо.

3 метою систематизації, узагальнення та контролю знань учнів під час уроку майбутні фахівці використовували тестові завдання, розроблені на платформах Mentimeter.com, Kahoot.com, Plickers.com, EasyTestMaker, MyTest, Socrative. Ці тестові платформи дають змогу провести опитування, тестові та зрізові завдання в інтерактивній ігровій формі. При цьому викладач мав можливість переглянути індивідуальні відповіді й оцінити успішність кожного учасника освітнього процесу.

Організація домашнього завдання, як й організація роботи класу загалом відбувалася на базі платформ Classdojo, Edmondo, GoogleClass, а також на платформі Learningapps, що давала змогу розміщувати завдання для конкретної групи учасників, у соціальних мережах 
(Instagram, Facebook) i програмах-комунікаторах (Messenger, Viber, Telegram, Whatsapp) тощо.

Для орієнтації студентів в інформаційному полі керівники пропедевтичної та педагогічної практики регулярно проводили консультації, тренінги, індивідуальні практикуми, коучинги, майстеркласи, онлайн заняття щодо використання інформаційнокомунікаційних технологій в освітньому процесі навчального закладу. Це сприяло ефективному формуванню інформаційної компетентності майбутніх учителів у процесі їхньої практичної підготовки.

\section{ВИСНОВКИ}

Отже, формування інформаційної компетентності майбутнього вчителя - це цілеспрямований процес, що забезпечується реалізацією завдань, змісту, форм і методів навчальної діяльності. Як результат, виробляється інформаційна грамотність (уміння ефективно шукати інформацію, уміння шукати та працювати зі джерелами й першоджерелами, розуміння авторського права й авторського контенту, уміння систематизувати інформацію), комп'ютерна грамотність (уміння працювати 3 програмами для скачування та обробки відео), розвиваються вміння й навички роботи 3 інформаційними джерелами, технологіями в умовах сучасного освітнього середовища; стимулюється інноваційність, креативність, свідоме використання наявних інструментів пошуку, обробки, аналізу інформації; прагнення до створення власного навчального контенту з урахуванням правил академічної доброчесності й особливостей використання інформаційно-комунікаційних технологій на різних етапах майбутньої педагогічної діяльності.

Практико-зорієнтоване навчання створює основу для засвоєння алгоритму майбутньої педагогічної діяльності: формуються базові операції, що становлять основу майбутніх інформаційнокомунікативних умінь; удосконалюються навички виконання базових операцій і стимулюється засвоєння складних комплексів робіт, що дають можливість виконувати діяльність самостійно на креативному рівні. I це відображає поетапну структуру формування інформаційної компетентності майбутнього вчителя.

Практико-зорієнтоване навчання повною мірою може забезпечити адаптацію майбутнього вчителя до професійної діяльності, сформувати здатність працювати в сучасному інформаційно-освітньому середовищі.

\section{АНОТАЦІЯ}

У статті обгрунтовано актуальність проблеми формування інформаційної компетентності майбутнього вчителя. Висвітлено 
можливості практико-зорієнтованого навчання у формуванні інформаційної компетентності майбутнього фахівця. Розкрито практичні аспекти цього напряму підготовки майбутнього вчителя на основі використання кращих зразків вітчизняного та зарубіжного педагогічного досвіду з метою пошуку інноваційних підходів до освітньої діяльності.

Розроблено методику формування інформаційної компетентності в процесі вивчення педагогічних і фахових дисциплін, що передбачала цілі, завдання, зміст, форми, методи, прийоми навчання, результативність. Процес формування інформаційної компетентності засобами практико-зорієнтованого навчання розглядається під час вивчення педагогічних i фахових дисциплін: «Методика виховної роботи», «Основи педагогічної майстерності», «Методика навчання іноземних мов», а також під час інструктивної, позашкільної, педагогічної практики здобувачів вищої освіти бакалавра.

Представлено сучасні освітні технології практико-зорієнтованого навчання, які забезпечують формування інформаційної, комп’ютерної грамотності, розвивають уміння та навички роботи з інформаційними джерелами, технологіями в умовах сучасного освітнього середовища, серед них - презентації, мультимедіа, прикладні офісні програми (Word, Excel, PowerPoint, Publisher), спеціалізовані програми (наприклад, Mathlab, GRAN, Maple тощо), програми для проведення тестів, педагогічні програмні засоби (ППЗ), електронні підручники, планшети, колекція цифрових освітніх ресурсів (ЦОР), мережа Інтернет (наприклад, бібліотека електронних наочних посібників), інтерактивна дошка, електронний класний журнал, використання локальної мережі, телекомунікації тощо. Методика спрямована на розвиток когнітивного, діяльнісного, цінніснорефлексивного, емоційно-вольового, етико-правового, комунікативного, адаптивного, здоров'язберігаючого структурних компонентів інформаційної компетентності майбутнього вчителя.

\section{ЛIТЕРАТУРА}

1. Бобраков С.В. Практико-зорієнтована спрямованість професійної підготовки вчителів у вищих навчальних закладах Німеччини : дис. ... канд. пед. наук : 13.00.01. Луганськ, 2014. 200 с.

2. Вем'ян В.Г., Тер-Ованес'ян В.Г. Дуальна форма професійної освіти як умова ефективного рішення завдань модернізації освіти. Психологія: реальність і перспективи. 2015. № 5. С. 29-34.

3. Горбенко Г.В. Практико-зорієнтоване навчання під час підготовки бакалаврів Інституту журналістики Київського університету імені Бориса Грінченка. Інтегровані комунікації. 2017. № 4. С. 80-86. 
4. Горбенко Г.В. Практико-зорієнтоване навчання у підготовці бакалаврів реклами і зв'язків з громадськістю. Неперервна професійна освіта: теорія і практика. 2015. Вип. 4 (45). С. 64-69.

5. Гузій I.C. Створення практико-зорієнтованого освітнього середовища як умова формування конкурентоздатності майбутніх педагогів професійного навчання комп'ютерного профілю в системі соціального партнерства. Обрії. 2017. № 2. С. 27-29.

6. Дернова М.Г. Дуальна модель вищої професійної освіти дорослих: європейський досвід. Освіта дорослих: теорія, досвід, перспективи. 2014. № 2. С. 137-145.

7. Інтеграція інфо-медійної грамотності у навчальний процес. Навчально-методичні матеріали проєкту «Вивчай та розрізняй: інфомедійна грамотність». Київ : IREX в Україні, 2019-2020.

8. Кадемія М.Ю., Кобися А.П., Кобися В.М. Дуальне навчання перспективна форма одержання вищої освіти. URL: http:/ito.vspu.net/ repozitariy/Kademiia/stati_19/st_19.pdf (дата звернення: 27.04.2020).

9. Калінічева Г. Дуальна форма навчання як пріоритетний напрям вищої професійної освіти в країнах європейського союзу. Ukraine European Union: From Partnership Towards Association. The Ukrainian Yearbook of the European Integration Studies. II. Lutsk : Teren, 2019. C. 151-163.

10. Квасницька Р.С. Практико-зорієнтований підхід як один із засобів професіоналізації навчання у вищих навчальних закладів. Модернізація економіки в умовах зростання суспільної свідомості: туризм, людиномірність, партнерство, кооперація : матеріали II Всеукраїнської науково-практичної інтернет-конференції (м. Полтава, 14 грудня 2017 р.). Полтава : ПУЕТ, 2017. С. 296-300.

11. Майковська B.I. Практико-зорієнтоване навчання як засіб професіоналізації підготовки майбутніх фахівців в Україні. Проблеми інженерно-педагогічної освіти. 2016. № 50-51. С. 161-167.

12. Маринченко Є.О. Дуальне навчання як важливий складник інноваційної підготовки майбутніх педагогів професійного навчання. Cherkasy University Bulletin: Pedagogical Sciences. 2019. № 1. C. 69-75.

13. Пальшкова I. Практико-зорієнтований підхід у формуванні професійно-педагогічної культури майбутніх вчителів початкових класів: теоретико-методологічний аспект : монографія. Одеса : Букаєв B.B., 2009. 339 c.

14. Про вищу освіту : Закон України від 28.12.2014 № 76-VIII. Дата оновлення: 18.03.2020. URL: https://zakon.rada.gov.ua/laws/show/1556-18 (дата звернення: 27.04.2020).

15. Про повну загальну середню освіту : Закон України від 16.01.2020 № 463-IX. URL: http://w1.c1.rada.gov.ua/pls/zweb2/ webproc4_1?pf3511=66333 (дата звернення: 27.04.2020). 
16. Про схвалення Концепції підготовки фахівців за дуальною формою здобуття освіти : Розпорядження Кабінету Міністрів України від 19 вересня 2018 p. № 660-p. URL: https://zakon.rada.gov.ua/ laws/show/660-2018-\%D1\%80 (дата звернення: 27.04.2020).

17. Проект «Шкільний учитель нового покоління». URL: http://www.britishcouncil.org.ua/teach/projects/presett (дата звернення: 27.04.2020).

18. Пропедевтична практика: програма для студентів ОКР «бакалавр». Галузь знань: 0203 «Гуманітарні науки», напрям підготовки: 6.020303 «Філологія. Мова і література (англійська)» / авт. Т.А. Авксентьєва, В.М. Галузяк, М.М. Гушеватий, Н.Б. Хамська, В.В. Каплінський ; Вінницький державний педагогічний університет імені М. Коцюбинського. Вінниця, 2012. 43 с.

19. Типова програма «Методика навчання англійської мови». Освітній ступінь бакалавра / О. Бевз, А. Гембарук, О. Гончарова, О. Заболотна, О. Змієвська, Л. Калініна, І. Каминін, Т. Коноваленко, I. Романишин, I. Самойлюкевич, О. Таран, Н. Тучина, К. Худик ; керівник проєкту: В. Іваніщева. Івано-Франківськ : НАІР, 2020. 126 с.

20. Хамська Н.Б. Робоча програма «Основи педагогічної майстерності» підготовки бакалаврів, галузі знань 01 Освіта/Педагогіка, за спеціальністю 014.02 Середня освіта (Мова і література (англійська, німецька, російська). Вінниця, 2019. 15 с.

21. Черв'якова Н.I. Практико зорієнтовані технології професійної підготовки майбутніх педагогів: досвід теоретико-експериментального дослідження. Education And Pedagogical Sciences. Ocвima ma педагогічна наука. 2017. № 1 (166). С. 35-43.

22. CDIO Standards 2.0. URL: http://www.cdio.org/implementingcdio/standards/12-cdio-standards (дата звернення: 27.04.2020).

23. Khamska N., Kynal A. Formation of Informational Competence of Future Teachers of Philological Specialties in the Process of Professional Training. Розвиток та модернізація педагогічних та психологічних наук: досвід Польщі та перспективи України. Development and Modernisation of Pedagogical and Psychological Sciences: Experience of Poland and Prospects of Ukraine : Collective Monograph. Vol. 3. Lublin : Izdevnieciba «Baltija Publishing», 2017. P. 206-225.

24. Kurbatov S. University Rankings and the Problem of Competitiveness of National Universities of Post-Soviet Countries in Global Educational Space: the Case of Ukraine. Evaluation in Higher Education. 2012. № 6 (2). P. 59-75.

25. Peercy M., Troyan F. Making transparent the challenges of developing a practice-based pedagogy of teacher education. Teaching and Teacher education. 2017. T. 61. C. 26-36. 
26. Pietsch S. Begleiten und begleitet werden. Praxisnahe Fallarbeit ein Beitragzur Professionalisierung in der universitären Lehrerbildung. Kassel : Kassel University Press, 2010. 294 s.

27. Post E.-M. Der Einsatz von handlungs-, erfahrungs und erlebnisorientierten Methoden in der Lehrerinnen und Lehrerfortbildung von pädagogischen Führungskräften zur Initiierung von Lernen. Studien zur Verknüpfung von Erfahrung, Reflexion und Transfer. Leipzig : Univ. Diss., $2010.791 \mathrm{~s}$.

28. SEED: Sweden's English Educational Database for tertiary education: Creating a platform for sharing and collaboration / $\mathrm{Ph}$. Shaw Philip, M. Deutschmann, R. Hincks, J. Hudson, D. Minugh. 2008. URL: https://www.researchgate.net/publication/237497727 (дата звернення: 27.04.2020).

29. Van der Wende M. The emergence of liberal arts and sciences education in Europe 1, 2: A Comparative Perspective. The Evolution of Liberal Arts in the Global Age. Routledge, 2017. C. 106-126.

30. Warneke D. Aktionsforschung und Praxisbezug in der DaFLehrerausbildung. Kassel : Kassel Univ. Press, 2007. 599 s.

31. Work-based learning in continuing vocational education and training: policies and practices in Europe. Luxembourg: Publications Office of the European Union, 2015. 78 c. URL: http://www.cedefop.europa.eu/ files/5549_en.pdf (дата звернення: 27.04.2020).

32. Work-Based Learning in Europe. Practices and Policy Pointers. European Comission. URL: http://ec.europa.eu/education/policy/vocationalpolicy/doc/alliance/work-based-learning-in-europe_en.pdf (дата звернення: 27.04.2020).

Information about the authors: Khamska N. B.,

Ph.D. in Pedagogical Sciences, Associate Professor at the Department of Pedagogy and Professional Education

Vinnytsia State Pedagogical University named after Mykhaylo Kotsybynskiy 32, Ostrozkogo str., Vinnytsia, Ukraine

Kynal A. Yu., Assistant at the Department of English Philology Vinnytsia State Pedagogical University named after Mykhaylo Kotsybynskiy

32, Ostrozkogo str., Vinnytsia, Ukraine 